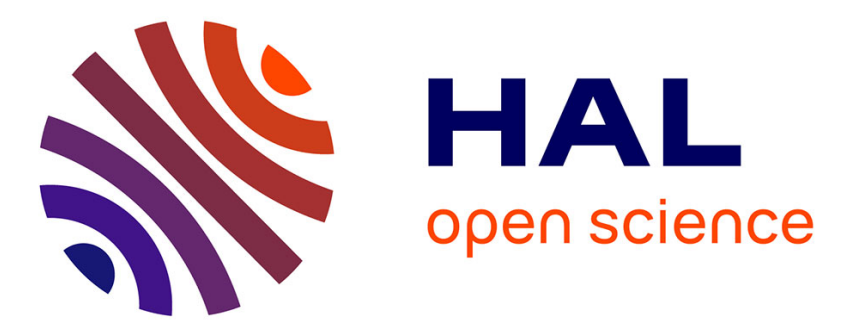

\title{
Magnetic stratigraphy of North Atlantic Sites 980-984
}

\author{
J.E.T. Channell, B. Lehman
}

\section{To cite this version:}

J.E.T. Channell, B. Lehman. Magnetic stratigraphy of North Atlantic Sites 980-984. Proceedings of the Ocean Drilling Program, 162 Scientific Results 1999, 162, Ocean Drilling Program, 1999, 10.2973/odp.proc.sr.162.002.1999 . hal-03118647

\section{HAL Id: hal-03118647 https://hal.science/hal-03118647}

Submitted on 22 Jan 2021

HAL is a multi-disciplinary open access archive for the deposit and dissemination of scientific research documents, whether they are published or not. The documents may come from teaching and research institutions in France or abroad, or from public or private research centers.
L'archive ouverte pluridisciplinaire HAL, est destinée au dépôt et à la diffusion de documents scientifiques de niveau recherche, publiés ou non, émanant des établissements d'enseignement et de recherche français ou étrangers, des laboratoires publics ou privés. 


\title{
8. MAGNETIC STRATIGRAPHY OF NORTH ATLANTIC SITES 980-984ํำ
}

\author{
J.E.T. Channell ${ }^{2}$ and B. Lehman ${ }^{3}$
}

\begin{abstract}
Magnetic polarity stratigraphies for Sites 980-984 are based on shipboard measurements from the pass-through magnetometer after alternating field (AF) demagnetization at a peak field of $25 \mathrm{mT}$ and shore-based stepwise AF demagnetization of discrete samples. The characteristic magnetization component was determined after AF demagnetization removed the steep downward drill-string-related magnetic overprint. Peak AF fields in the 20-30 mT range were required to resolve the component, carried by magnetite, that was used to produce unambiguous Pliocene-Pleistocene magnetic stratigraphies at all five sites. At Sites 980 and 983, magnetic stratigraphies were resolved to the base of the recovered advanced hydraulic piston corer (APC) section, which lies in the Matuyama Chron (1r.2r) and Olduvai Subchron (2n), respectively. At Sites 981 and 982, magnetization intensities decrease sharply in the normal polarity zone corresponding to the Gauss Chron (2An), and magnetic stratigraphies below this level could not be resolved. At Site 984 , the resolution of magnetic stratigraphy was curtailed at $\sim 250$ meters below seafloor (Olduvai Subchron) by core deformation at the base of the APC section and in the underlying extended core barrel section.

As the magnetic stratigraphies at all four sites are unequivocal, polarity chron interpretations can be made without aid from the biostratigraphy. Mean sedimentation rates within polarity chrons have been calculated and Pliocene-Pleistocene biomagnetostratigraphic correlations tested.
\end{abstract}

\section{INTRODUCTION AND METHODS}

The North Atlantic sites drilled during Ocean Drilling Program (ODP) Leg 162 (Sites 980-984) were located on the Rockall Bank (Site 982), off its southern edge (Sites 980/981), and on the Gardar (Site 983) and Bjorn Drifts (Site 984) (Fig. 1). Archive halves of all core sections were measured on board ship using the cryogenic passthrough magnetometer. The high rate of core recovery at these sites required that cores be processed promptly and, therefore, stepwise alternating field (AF) demagnetization was generally not feasible during the cruise. Most core sections were measured on board ship at a single demagnetization step (generally $25 \mathrm{mT}$ ), the choice of peak field being based on stepwise demagnetization of a few core sections and a handful of discrete samples.

Subsequent shore-based discrete sample measurements were necessary to "ground truth" the shipboard magnetic stratigraphy. These samples were collected during the cruise in standard $7-\mathrm{cm}^{3}$ plastic boxes and measured at laboratories at Gif-sur-Yvette and at the University of Florida. Natural remanent magnetization was measured before demagnetization and during stepwise $\mathrm{AF}$ demagnetization using a peak field increment of $5 \mathrm{mT}$ in the 5-70 $\mathrm{mT}$ range, or until the magnetization intensity fell below magnetometer noise level. Orthogonal projections of AF demagnetization data indicated a characteristic magnetization component resolved at peak fields over $\sim 20$ $\mathrm{mT}$. A lower coercivity component was observed in most samples, particularly those with a reverse polarity characteristic component. The low-coercivity component is oriented steeply downcore and is probably partly a viscous remanent magnetization imposed by the drill-string assembly and partly a stirred remanent magnetization related to sediment drilling disturbance. The AF range in which the characteristic magnetization component is isolated was picked by eye from orthogonal projections. The direction of the discrete sample characteristic magnetization component was determined using the

${ }^{1}$ Raymo, M.E., Jansen, E., Blum, P., and Herbert, T.D. (Eds.), 1999. Proc. ODP, Sci. Results, 162: College Station, TX (Ocean Drilling Program)

2Department of Geology, University of Florida, Gainesville, FL 32611-2120, U.S.A. jetc@nersp.nerdc.ufl.edu

${ }^{3}$ Laboratoire des Sciences du Climat et de l'Environnement, CNRS-CEA, Avenue de la Terrasse, 91198 Gif-sur-Yvette, France. standard least-squares technique (Kirschvink, 1980). The discrete sample data generally confirmed the shipboard pass-through measurements, but in some cases, notably in the vicinity of the Gauss/ Matuyama boundary at Site 981, the shipboard measurements did not isolate the characteristic magnetization component.

\section{SITE 980}

Orthogonal projections of progressive AF demagnetization (Fig. 2) of discrete samples from Hole 980A indicated that a characteristic component is well defined in the $20-70 \mathrm{mT}$ AF demagnetization range. Magnetization intensities were reduced to values close to magnetometer noise level after demagnetization at 60-70 $\mathrm{mT}$, indicating the absence of high-coercivity remanence carriers. Characteristic component inclinations from discrete samples (open squares in Fig. 3) are generally consistent with shipboard data from Hole 980A. The positions of polarity chron boundaries indicate that the base of the hole lies in the Matuyama Chron (1r.2r). The Jaramillo Subchron and the Brunhes/Matuyama boundary are well defined. Note that the differences in the values of meters below seafloor (mbsf) corresponding to polarity zone boundaries at the three holes (Fig. 3) are taken into account by the calculation of meters composite depth (Table 1). See Shipboard Scientific Party (1996a) for an explanation of the technique used to calculate composite depths for Leg 162 sites.

\section{SITE 981}

Orthogonal projections of AF demagnetization of samples from Hole 981A indicated that a well-defined magnetization component is resolved at peak fields above $20 \mathrm{mT}$ (Fig. 4). For samples from this site, however, magnetization intensities after demagnetization at peak fields of $25 \mathrm{mT}$ decrease sharply at $\sim 150 \mathrm{mbsf}$ (Fig. 5A), close to the Gauss/Matuyama boundary. The decrease in intensity, by almost two orders of magnitude, coincides with the transition from lithostratigraphic Unit I to Unit II. The mean carbonate content of Unit II is $80.1 \mathrm{wt} \%$, whereas Unit I has a mean carbonate content of 44.8 wt\% (Shipboard Scientific Party, 1996b). The increase in car- 
Figure 1. Location map for Sites 980-984. Site 981 lies 2 nmi southeast of Site 980.

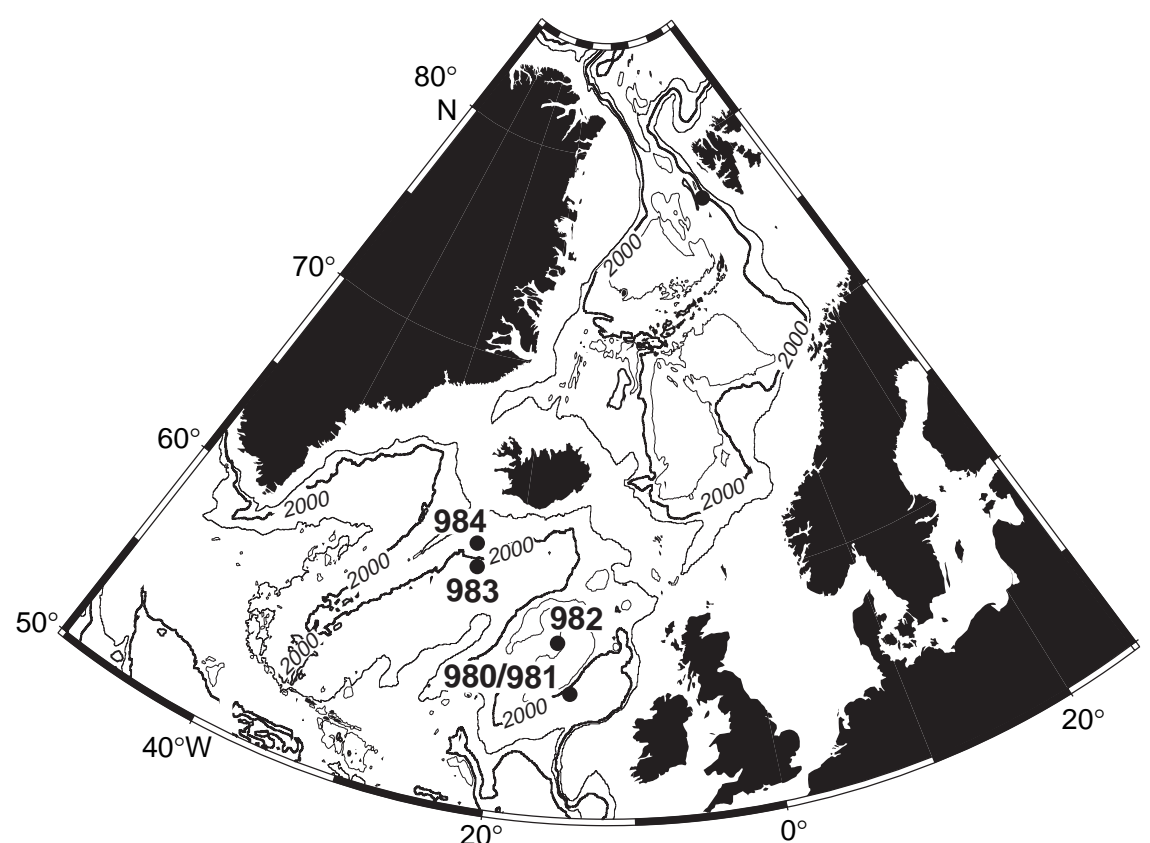

The event is included in calculation of sedimentation rates (Table 2). The variable inclination values within the Matuyama Chron may indicate both instability of the geomagnetic field at this time and poorly resolved characteristic magnetization components. Short polarity events (Cobb Mountain and the Gilsa Events) have been recognized between the Jaramillo and the Olduvai Subchrons at Hole 609B (ODP Leg 94) (Clement and Kent, 1987). These events appear to be recorded at Site 983 , where sedimentation rates are approximately twice those at Hole 609B. The Cobb Mountain Event is tentatively identified, included in the sedimentation rate calculations (Table 2), and assigned an age of 1.21 Ma (Berggren et al., 1995).

\section{SITE 984}

Orthogonal projections of AF demagnetization data for samples from Hole 982B indicate that the characteristic magnetization components are well defined down to $\sim 70$ mbsf (Figs. 8, 9). Below this level, magnetization intensities are too low for precise definition of the characteristic component. In the shipboard pass-through data, the decrease in magnetization intensity occurs in the 50-60 mbsf interval (Fig. 5B). As at Site 981, the abrupt decrease in magnetization intensity coincides with the change in carbonate content from mean values of 57.7 to $90.8 \mathrm{wt} \%$, at the boundary between lithostratigraphic Units I and II (Shipboard Scientific Party, 1996c). The concentration of magnetite changes abruptly at the same level, as indicated by the change in multisensor track susceptibility values (Fig. 6B).

\section{SITE 983}

The ubiquitous downward magnetic overprint is also present at Site 983; however, it can be eliminated by AF demagnetization at peak fields of $20 \mathrm{mT}$ (Fig. 10). The characteristic magnetization component is particularly well defined at this site, with maximum angular deviation (MAD) values $<5^{\circ}$. The base of the recovered section lies within the Olduvai Subchron at Hole 983A and Hole 983B, and just below the Olduvai Subchron at Hole 983C (Fig. 11). Note the presence of one well-defined interval of negative inclinations within the Brunhes Chron in the 15-20 mbsf depth range. This event has an age of $188 \mathrm{ka}$, occurring close to the oxygen isotopic Stage 6/7 boundary, and has been named the Iceland Basin Event (Channell et al., 1997).
Orthogonal projections of AF demagnetization of samples from this site indicated that a well-defined characteristic magnetization component could be resolved after removal of the steep downward drill-string overprint (Fig. 12). MAD values were usually $<10^{\circ}$. The discrete sample component directions from Hole 984B corroborate the shipboard pass-through data (Fig. 13). Below 260 mbsf at Hole 984B, the shipboard pass-through data are compromised by drillingrelated deformation at the base of the advanced hydraulic piston corer (APC) section. As at Site 983, the Iceland Basin Event at $188 \mathrm{ka}$ is observed within the Brunhes Chron, and the interval between the Jaramillo and the Olduvai Subchrons appears to be an interval of geomagnetic instability. The Cobb Mountain Event is tentatively identified below the Jaramillo Subchron and is included in the interval sedimentation rate calculations (Table 2).

\section{SEDIMENTATION RATES AND BIOSTRATIGRAPHIC CORRELATIONS}

Before Leg 162, conventional piston cores had shown that the sedimentation rates were high in the uppermost $\sim 15 \mathrm{~m}$ on the Feni, Gardar, and Bjorn Drifts. It was not known, however, whether these high sedimentation rates continued at depth or whether the drift deposition was interrupted by unconformities. From the magnetic stratigraphy, sedimentation rates within the Brunhes Chron are comparable at Feni (Site 980), Gardar (Site 983), and Bjorn (Site 984) (Fig. 14; 


\section{Hole $980 \mathrm{~A}$}
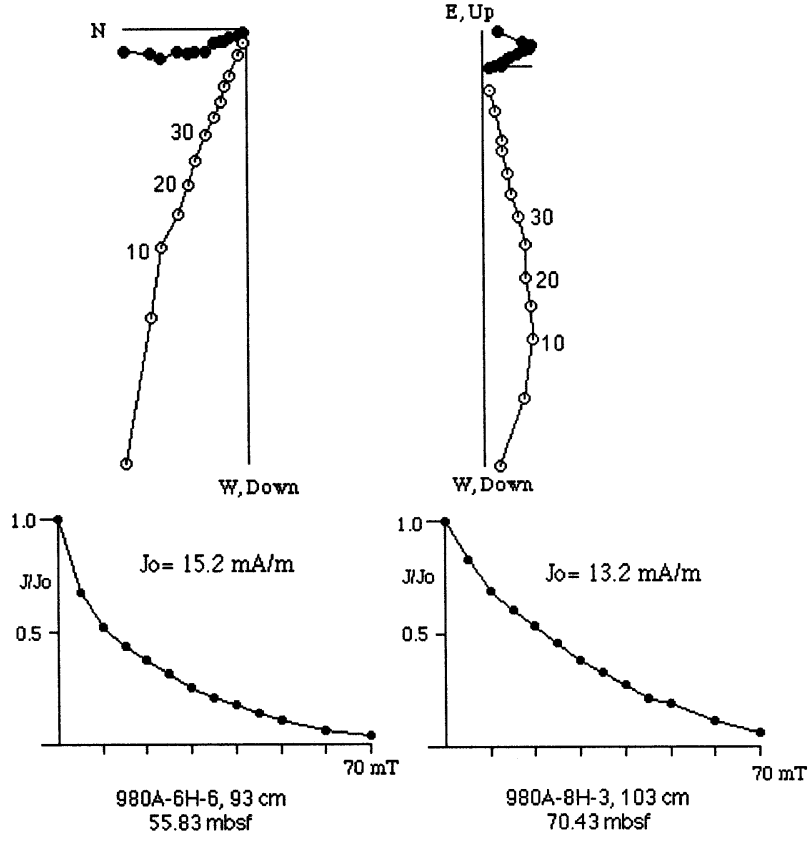

$70.43 \mathrm{mbsf}$
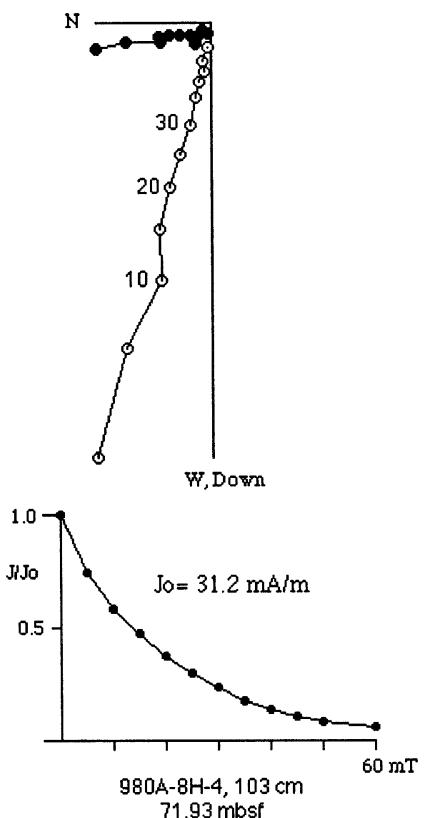

$71.93 \mathrm{mbsf}$
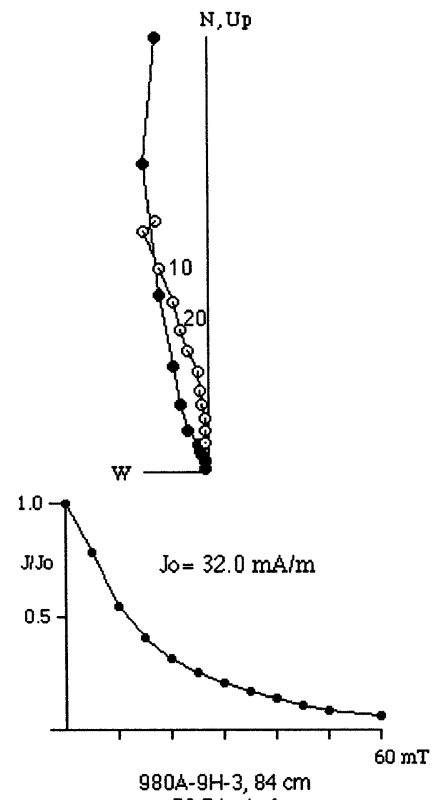

$79.74 \mathrm{mbsf}$
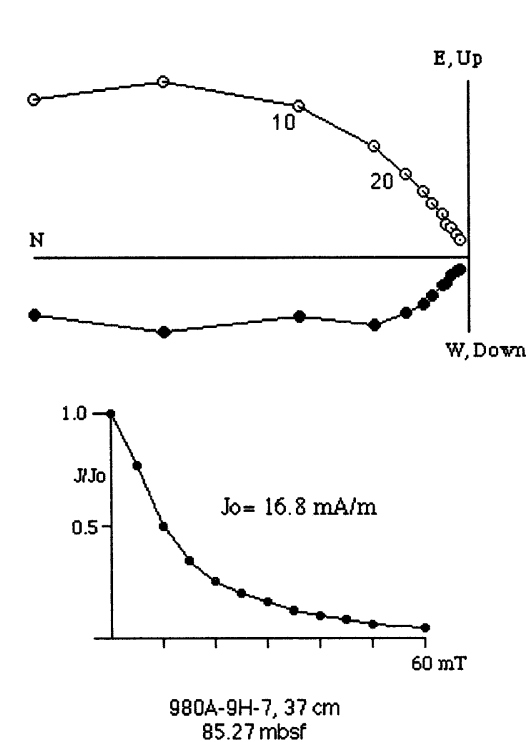
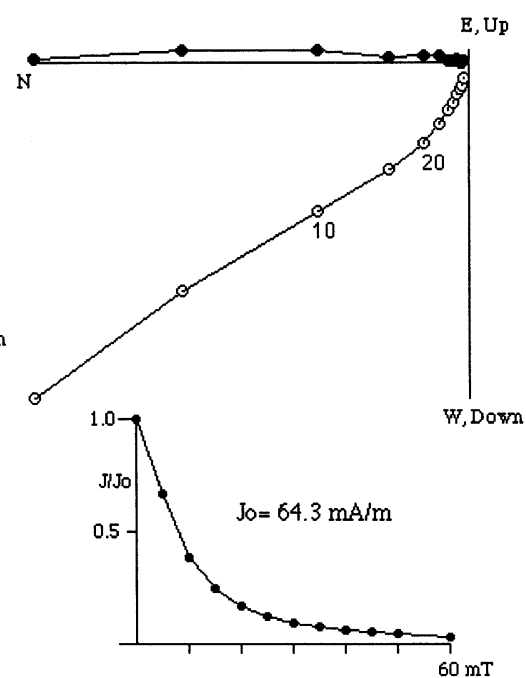

$980 \mathrm{~A}-10 \mathrm{H}-1,100 \mathrm{~cm}$ $86.40 \mathrm{mbs}$

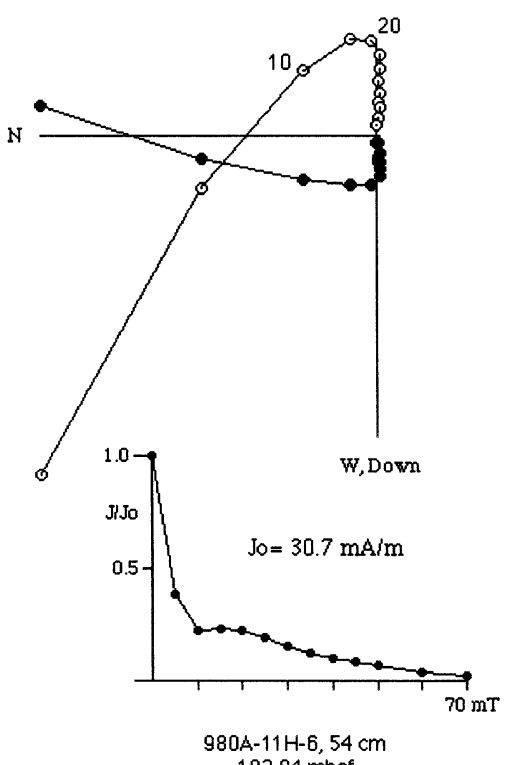

102.94 mbsf

Figure 2. Orthogonal projection of AF demagnetization data from discrete samples in the 50-110 mbsf interval of Hole 980A. Open and solid symbols indicate projections on the vertical and horizontal planes, respectively. $\mathrm{J}_{0}=$ magnetization intensity before demagnetization.

Table 2). At the second site on the Feni Drift (Site 981), Brunhes sedimentation rates are lower than at Site 980. This was expected from the seismic stratigraphy linking Sites 980 and 981 . The upper Pleistocene deposits are seen to thicken toward Site 980, and the Pliocenelower Pleistocene deposits thicken toward Site 981 (Shipboard Scientific Party, 1996b). The lack of data in the lower parts of the sections at Sites 981 and 982 (Fig. 14) was caused by decreasing magnetization intensities at $\sim 150$ and 60 mbsf, respectively, at these two sites (Fig. 5). The lack of data at the base of the section at Site 984 (Fig. 14) resulted from core deformation at the base of the APC section.
In the intervals for which we have magnetostratigraphic control, no abrupt changes in sedimentation rates are apparent (Fig. 15). As expected from the seismic stratigraphy, sedimentation rates at Site 980 decrease with depth and those at Site 981 increase with depth. At the top of the section, Site 984 sedimentation rates are high relative to those at Site 983; however, the converse is true in the lower part of the two magnetostratigraphic sections (Fig. 15; Table 2). All sites that record the Reunion Event at 2.14-2.15 Ma, particularly Site 981, show a step in the age-depth curve. This may indicate a problem with the duration of the Reunion Event (10 k.y.) in the time scale used (Cande and Kent, 1995). At Sites 981, 982, and 984, the Reunion 


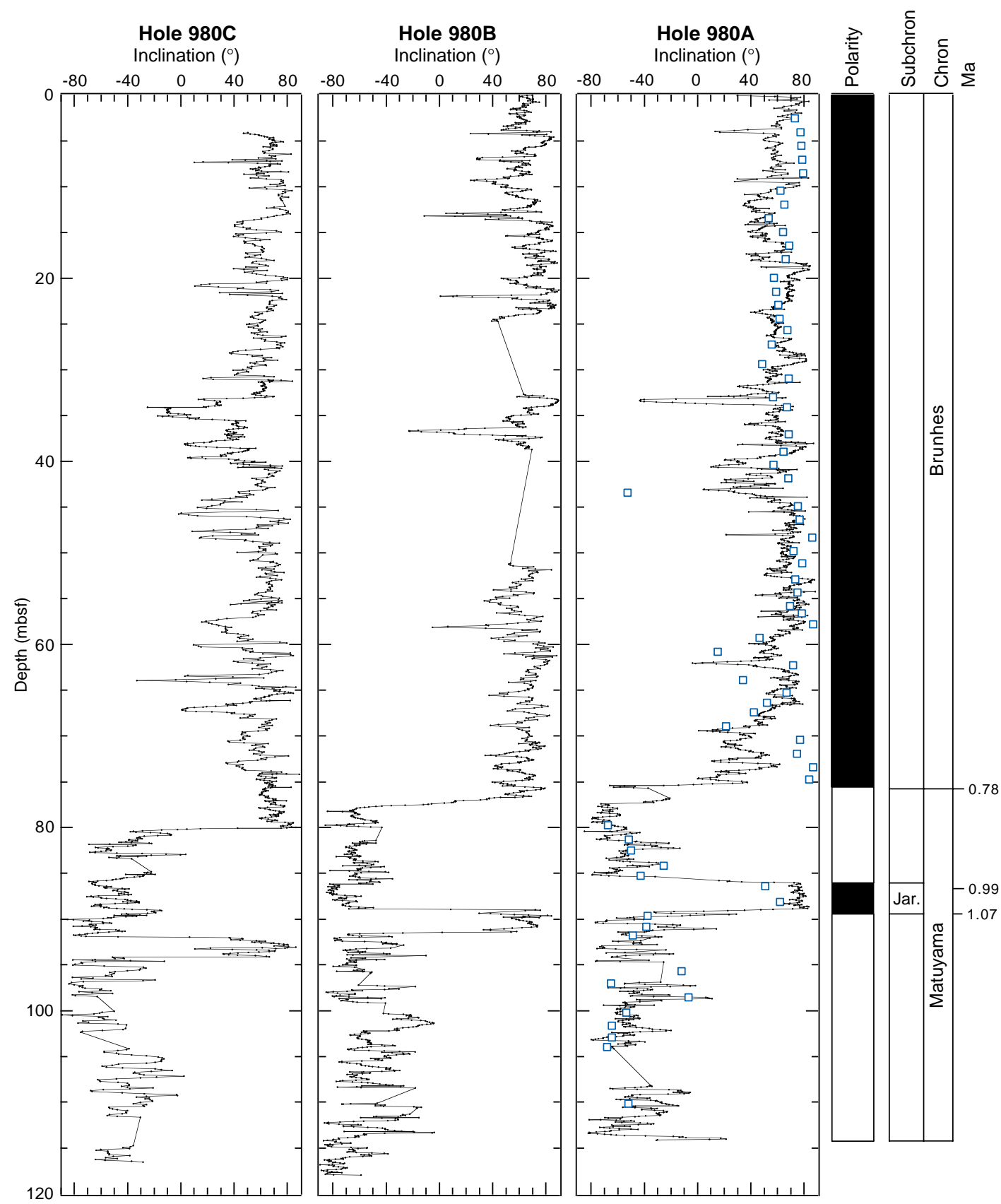

Figure 3. Shipboard (pass-through magnetometer) inclination data after AF demagnetization at peak fields of $25 \mathrm{mT}$ for Site 980 in the $0-120 \mathrm{mbsf}$ interval. Open squares indicate component inclinations determined from discrete $\left(7 \mathrm{~cm}^{3}\right)$ samples measured postcruise. Component directions were computed from orthogonal projections of AF demagnetization data. Jar. = Jaramillo.

Event is inexplicably expanded on this time scale. The Cande and Kent (1992) time scale assigned a duration of 32 k.y. to the Reunion Subchron, which results in more uniform sedimentation rates in the vicinity of the Reunion Subchron at both Sites 983 and 984 (Table 2).

The quality of the magnetic stratigraphies at Sites 980-984 is such that magnetostratigraphic (polarity chron) interpretations can be made without the guidance of biostratigraphic datums. For this reason, Sites 980-984 provide a useful reference for late Pliocene-Pleistocene biomagnetostratigraphic correlations. The superposition (ordering) of biostratigraphic events is generally consistent among the four sites (Fig. 16); however, the correlations of biostratigraphic events with polarity chrons show some variations. For example, the Gephyrocapsa spp. events occur between the Olduvai Subchron and just above the Brunhes/Matuyama boundary. The exact positions of each of these events vary, however, from site to site (Fig. 16). Assuming uniform sedimentation rate within polarity chrons, we have calculated the age of well-defined biostratigraphic events and compared these ages with the compilation of Berggren et al. (1995) (Table 3). Although the site with the lowest sedimentation rates (Site 982) yields the more inconsistent ages of bioevents, these ages are generally consistent with the Berggren et al. (1995) compilation.

\section{ACKNOWLEDGMENTS}

We thank C. Kissel and C. Laj for logistical support, K. Huang for laboratory assistance, and B. Clement and G. Muttoni for reviews of the manuscript. The paleomagnetic laboratory at Gif-sur-Yvette is 


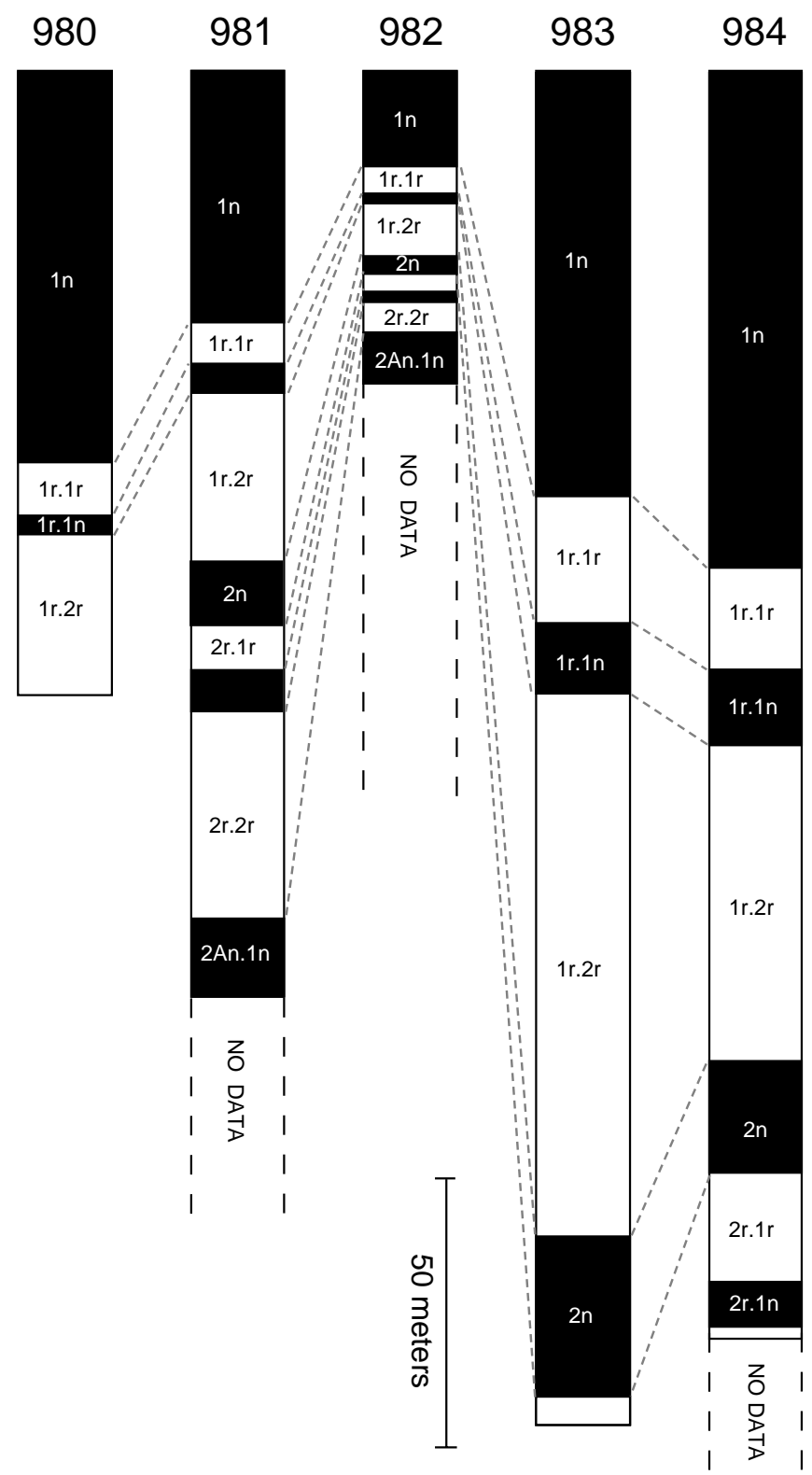

Figure 14. Magnetic polarity stratigraphies from Sites 980 to 984 on a uniform vertical (depth) scale. Polarity chron nomenclature from Cande and Kent (1992).

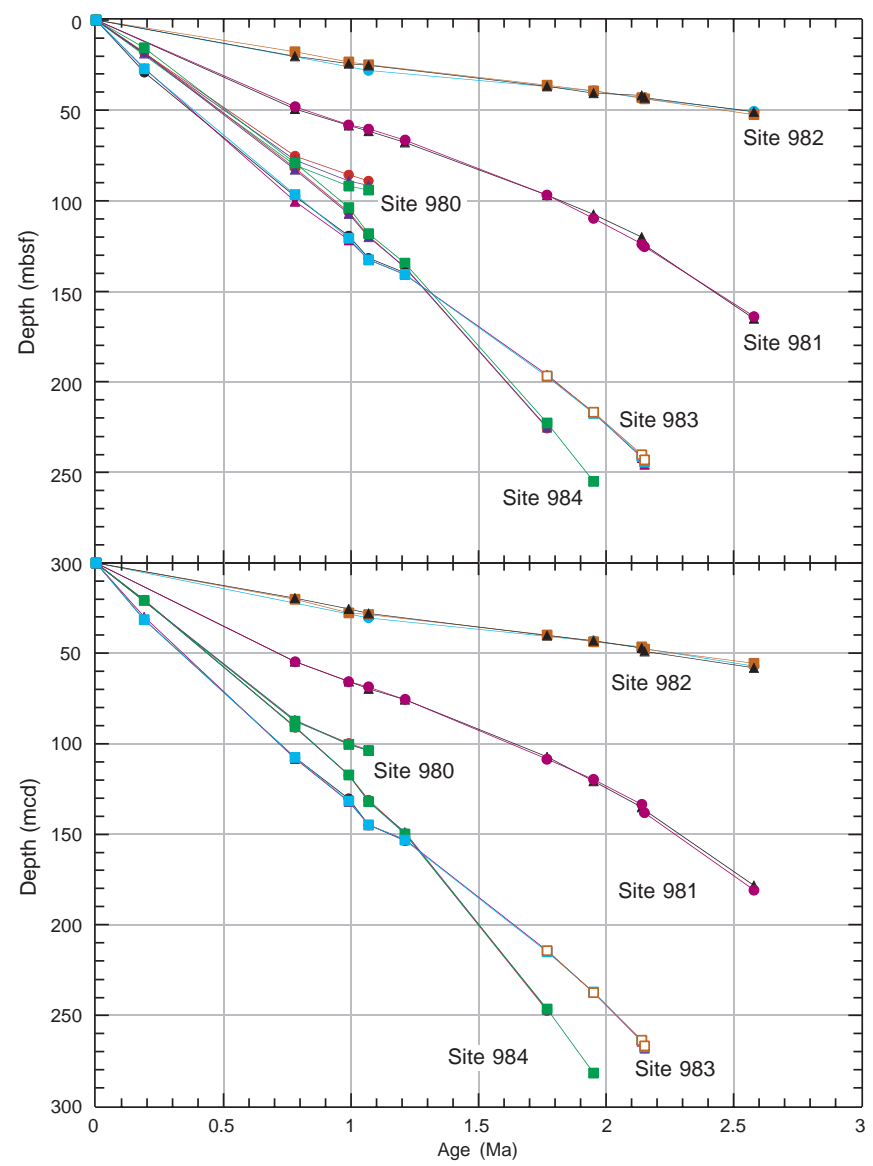

Figure 15. Age-depth plots based on magnetostratigraphic interpretations for individual holes from each site. Top $=$ meters below seafloor, base $=$ meters composite depth. 